\title{
As práticas mortuárias na região da Argólida entre os séculos XI e VIII a.C.
}

\author{
Camila Diogo de Souza*
}

SOUZA, C.D. As práticas mortuárias na região da Argólida entre os séculos XI e VIII a.C. Revista do Museu de Arqueologia e Etnologia, São Paulo, 20: 197-217, 2010.

Resumo: $O$ presente artigo visa apresentar resumidamente os objetivos e os principais resultados da pesquisa de doutorado desenvolvida no MAE/USP sobre as práticas mortuárias nos principais sítios da região da Argólida, Grécia (Mapa), durante a Idade do Ferro, entre os séculos XI e VIII a.C. Tal pesquisa caracteriza-se pelo levantamento, pela catalogação e pelo exame exaustivo dos vestigios arqueológicos dos contextos funerários em Argos, Tirinto, Asine, Micenas, Náuplia e Lerna. Por fim, a comparação de tais dados entre si possibilitou o levantamento de considerações sobre padrões de enterramento e de comportamento sócio-cultural inseridos numa perspectiva regional de análise direcionada, principalmente, para o século VIII a.C., com o processo de formação da pólis argiva.

Palavras-chave: Contextos funerários - Idade do Ferro - Argólida - Século VIII a.C.

O estudo dos contextos funerários tem sido objeto de diferentes áreas disciplinares há décadas como, por exemplo, a arqueologia e a antropologia. O aparato teóricometodológico desenvolvido a partir das diferentes linhas interpretativas fundamentadas na Arqueologia da Morte ${ }^{1}$ tem elucidado inúmeros aspectos da relação entre contextos funerários e a sociedade que os produziu. Entretanto,

(*) Doutora em Arqueologia pelo Museu de Arqueologia e Etnologia da Universidade de São Paulo.

<caumilasouza@yahoo.com>

(1) $O$ termo Arqueologia da Morte, a principio, não denota tais preocupações e pode indicar uma abordagem genérica da morte, a partir de seus aspectos abstratos, contraditoriamente aos pressupostos arqueológicos. O termo Arqueologia das Práticas Mortuárias foi formalmente cunhado e definido na dissertação de mestrado defendida por M. Ribeiro, Uma Abordagem Historiográfica assumir uma posição dogmática em relação às linhas teórico-metodológicas pode gerar uma abordagem tendenciosa e enviesada do material proveniente dos contextos funerários, pois o arqueólogo preocupa-se em primeiro lugar com o corpo teórico-metodológico em detrimento das informações disponiveis no material arqueológico que está analisando. É exatamente a partir do material reunido que se aplicam e

da Arqueologia das Práticas Mortuárias, na Faculdade de Filosofia, Letras e Ciências Humanas da Universidade de São Paulo, em 2002. Concordamos com a autora sobre as especificações e os usos do termo, e acreditamos que se trata de um termo mais apropriado em relação aos estudos sobre a morte no campo arqueológico devido à ênfase atribuida às práticas rituais e ao produto material resultante dessas práticas, portanto, a cultura material, objeto de estudo do arqueólogo. 
definem os métodos e o corpo teórico coerentes com a análise do mesmo. São as questões colocadas ao corpus documental que devem estabelecer a metodologia de análise e a abordagem teórica mais adequadas.

O contexto funerário é constituído por uma série de elementos que envolvem um conjunto de práticas rituais. De um lado, os contextos funerários são formados essencialmente pelo conjunto da cultura material com a qual o arqueólogo se depara, isto é, o túmulo com ou sem algum tipo de marca, sinal (uma lápide, por exemplo), e seu conteúdo, os restos ósseos humanos e os objetos depositados com o morto (o que se denomina correntemente de mobiliário funerário). De outro, os contextos funerários correspondem ao conjunto de práticas rituais executadas pelos vivos no momento em que um individuo pertencente a uma comunidade morre, como, por exemplo, a exposição e a lamentação do morto, o cortejo fúnebre e as cerimônias executadas um determinado tempo após a morte do indivíduo, como uma missa ou as incursões regulares dos familiares ao túmulo em uma data especifica. Muitas vezes, esse conjunto de exéquias dificilmente é reconhecido apenas a partir do registro arqueológico. Dessa maneira, os enterramentos, apesar de constituem uma pequena parte do conjunto de atividades cerimoniais que envolvem a morte (Morris 1987: 29), isto é, das práticas mortuárias, apresentam uma série de variáveis passiveis de análise que nos levam, em última instância, a reflexões sobre a organização da sociedade. Fundamentalmente, tais variáveis dizem respeito a três aspectos (Binford 1971: 21) que, a partir da documentação levantada para a pesquisa, incluem os atributos estabelecidos abaixo:

1) Tratamento do corpo - inclui os atributos idade, gênero, tipo de enterramento (inumação/cremação) e, nos casos de inumação, orientação (ponto cardeal considerado para a deposição do crânio) e posição do corpo (estendida /contraida);

2) Local de deposição do corpo abrange tipos de sepultura e a localiza- ção das sepulturas em relação às áreas de habitação; e

3) Configuração do mobiliário funerário - tipo de material (cerâmica/ metais), quantidade de artefatos, dimensões e aspectos qualitativos (processo de fabricação e elementos de ornamentação).

Tais atributos das práticas mortuárias envolvem dimensões simbólicas que, de um lado, concernem às escolhas pessoais do defunto e suas próprias conquistas em vida e, de outro, dizem respeito aos papéis e às relações sociais estabelecidas com um grupo na vida e na morte, isto é, as definições da persona social do morto (Binford 1971: 19-21; Saxe 1970: 6-7). O primeiro aspecto é considerado como o "pesadelo do arqueólogo" (Ucko 1969: 273), sendo muito difícil de ser identificado apenas através da cultura material. $\mathrm{O}$ segundo aspecto simbólico das práticas mortuárias, vale dizer, o estabelecimento da persona social, também não constitui um ofício simples de ser realizado, principalmente em relação aos aspectos da organização social. Os enterramentos não devem ser compreendidos como um simples espelho, reflexo das relações sociais da vida real. O conjunto simbólico das práticas mortuárias constitui um sistema de representações aprovado socialmente das relações estabelecidas entre os individuos e entre os grupos sociais, caracteristica que leva ao entendimento dos contextos funerários, em parte, como uma forma de reafirmação da ordem social, seja pela isonomia das identidades ou pela marca de suas diferenças através da execução dos rituais funerários (Morris 1987: 29-43).

É neste sentido que buscamos entender os contextos funerários da Argólida datados da Idade do Ferro. A região da Argólida localiza-se no Peloponeso e é formada por uma extensa planície de aproximadamente $200 \mathrm{~km}^{2}$ (Mapa). Nesta área se encontram as principais cidades atuais da região que apresentam vestigios arqueológicos desde o Neolitico. Tais comunidades tiveram um desenvolvimento independente e singular e que pode ser considerado de suma importância no processo de formação da 


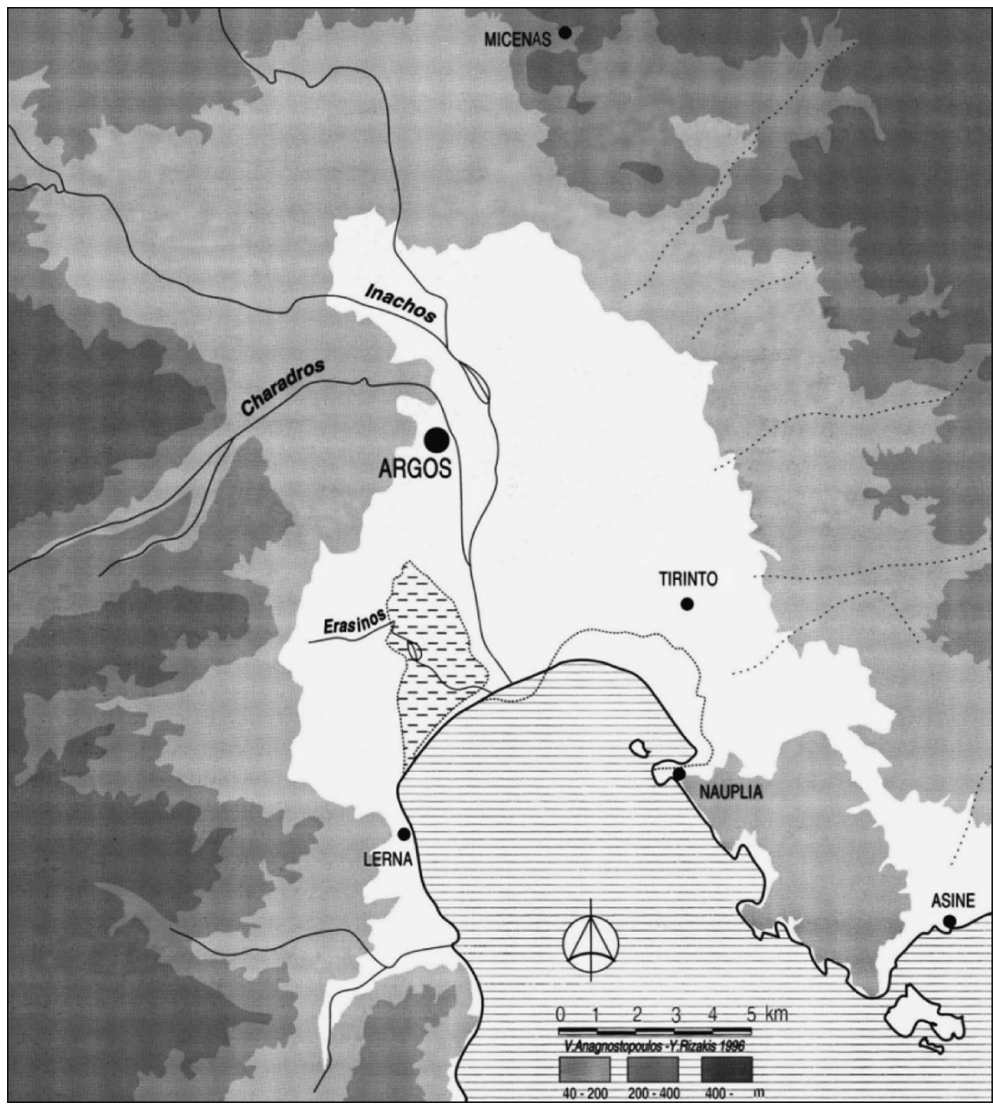

Mapa da região da Argólida (Piérart 1996: 10).

pólis na história da Grécia Antiga, ao lado de cidades como Atenas, por exemplo. Mesmo com a dissolução do sistema palacial micênico durante o Heládico Recente IIIB, por volta de 1200 a.C., seguida por um periodo marcado por profundas mudanças em todos os aspectos da vida, Argos, Tirinto e Micenas apresentam traços de ocupação continua manifestados pela presença de vestigios cerâmicos, e habitacionais, mas, sobretudo, pela presença de contextos funerários.

A partir de 1100 a.C. inicia-se a denominada Idade do Ferro, composta por três subperiodos fundamentais: Submicênico, Protogeométrico e o Geométrico. A produção cerâmica na Argólida, desde o Submicênico, apresenta caracteristicas estilisticas próprias que proporcionam especificidades cronológicas para os subperiodos da Idade do Ferro, distinguindo-os da cronologia estabelecida para a Ática. Dessa forma, para a região da Argólida, o Submicênico (SM) abrange aproximadamente entre $1100 \mathrm{e}$
1050. ${ }^{2}$ O Protogeométrico (PG) corresponde a um longo período que vai desde a primeira metade do século IX até o final do século X, por volta de 900 . Neste momento, inicia-se o Periodo Geométrico $(G)$, que pode ser dividido em outros três grandes subperiodos, o Geométrico Antigo (GA), de 900 a 825, seguido do Geométrico Médio (GM), entre 825 e 750 e, finalmente, o Geométrico Recente (GR), correspondente à segunda metade do século VIII a.C. Cada subperiodo do Geométrico pode ser ainda dividido em I e II.

O levantamento dos contextos funerários datados da Idade do Ferro nesta região possibilitou a reunião de, no mínimo, 824 enterramentos que formam o corpus documental da pesquisa de doutorado, composto por um catálogo e dois

(2) Todas as datas referidas no texto são a.C. 
bancos de dados, um em Excel e outro em FileMaker. Tal recurso, inédito para a região da Argólida e para o periodo de estudo selecionado, permite a inclusão de informações e dados e viabiliza, dessa maneira, perspectivas futuras de análise deste vasto material, a partir de abordagens distintas, procurando entender de uma forma cada vez mais detalhada as práticas mortuárias da região da Argólida durante a Idade do Ferro (Souza 2010). A totalidade de sepultamentos catalogados pode ser distribuida a partir da Tabela 1 a seguir.
A caracteristica marcante dos costumes funerários nos principais sítios da região diz respeito ao tipo de sepultamento. Durante toda a Idade do Ferro e em todos os sítios, a inumação constitui a prática de enterramentos majoritária e padrão para os indivíduos, sejam adultos ou crianças do sexo masculino ou feminino (Tabelas 2 e 3).

Além disso, notamos que há três tipos de sepulturas utilizadas de forma variada durante os subperiodos da Idade do Ferro: os túmulos em cista, em vasos funerários e em cova

\section{Tabela 1}

Número total de enterramentos da Idade do Ferro nos sítios da Argólida.

\begin{tabular}{lccccccr}
\hline \hline Sítio / Período & SM & PG & GA & GM & GR & G & Total \\
\hline Argos & 14 & 106 & 68 & 53 & 119 & 160 & 520 \\
Tirinto & 10 & 43 & 21 & 19 & 30 & 16 & 139 \\
Asine & - & 64 & - & - & 6 & 5 & 75 \\
Micenas & 4 & 15 & 1 & 4 & 9 & - & 33 \\
Naúplia & 4 & - & 1 & 1 & 17 & 5 & 28 \\
Lerna & - & - & 2 & 17 & 1 & 9 & 29 \\
\hline & 32 & 228 & $\mathbf{9 3}$ & $\mathbf{9 4}$ & $\mathbf{1 8 2}$ & $\mathbf{1 9 5}$ & $\mathbf{8 2 4}$
\end{tabular}

Tabela 2

\begin{tabular}{lccccccr}
\hline \multicolumn{7}{c}{ Enterramentos infantis da Idade do Ferro nos sítios da Argólida. } \\
\hline \hline Sítio / Periodo & SM & PG & GA & GM & GR & G & Total \\
\hline Argos & 2 & 28 & 12 & 7 & 27 & 26 & 102 \\
Tirinto & 1 & 14 & 3 & 3 & 7 & 1 & 29 \\
Asine & - & 28 & - & - & 3 & - & 31 \\
Micenas & 3 & 9 & - & - & 3 & - & 15 \\
Naúplia & - & - & - & - & 4 & 1 & 5 \\
Lerna & - & - & 2 & 2 & 1 & - & 5 \\
\hline & 6 & 79 & $\mathbf{1 7}$ & $\mathbf{1 2}$ & $\mathbf{4 5}$ & $\mathbf{2 8}$ & $\mathbf{1 8 7}$
\end{tabular}

Tabela 3

\begin{tabular}{lccccccc}
\hline \multicolumn{7}{c}{ Enterramentos de adultos da Idade do Ferro nos sítios da Argólida. } \\
\hline \hline Sítio / Periodo & SM & PG & GA & GM & GR & G & Total \\
\hline Argos & 12 & 78 & 56 & 46 & 92 & 134 & 418 \\
Tirinto & 9 & 29 & 18 & 16 & 23 & 15 & 110 \\
Asine & - & 36 & - & - & 3 & 5 & 44 \\
Micenas & 1 & 6 & 1 & 4 & 6 & - & 18 \\
Naúplia & 4 & - & 1 & 1 & 13 & 4 & 23 \\
Lerna & - & - & - & 15 & - & 9 & 24 \\
\hline & 26 & $\mathbf{1 4 9}$ & 76 & 82 & 137 & 167 & $\mathbf{6 3 7}$
\end{tabular}


simples. A cista corresponde, em geral, a uma fossa revestida e coberta com grandes placas ou várias pedras de calcário. Os vasos funerários são representados, na grande maioria das vezes, por pitos, crateras e ânforas de grande porte. Já a cova simples é identificada por uma fossa sem revestimento, porém, em alguns casos, coberta com placas ou pedras de calcário. A distribuição dos enterramentos nos subperiodos da Idade do ferro a partir do atributo tipo de sepultura pode ser visualizada nas Tabelas 4, 5 e 6 . A partir desses parâmetros, o principal objetivo da pesquisa constitui o exame dos atributos das práticas mortuárias em cada subperiodo da Idade do Ferro, a fim de visualizar principalmente os processos de mudanças de comportamento em relação a tais práticas, à configuração da ordem social e ao processo de interação entre as comunidades. ${ }^{3}$

\section{O Submicênico $(\mathrm{SM})$ : rupturas e reminiscências}

Em primeiro lugar, podemos afirmar que o número total de enterramentos datados do SM na Argólida é bem pequeno quando comparado aos demais subperiodos da Idade do Ferro, principalmente em relação ao PG e ao GR (Tabela 1). Tal fato pode significar um periodo de adaptação às mudanças sociais e politicas decorrentes do colapso do Heládico Recente IIIB e nos remete à questão da visibilidade dos enterramentos, relacionada com as definições da persona social do morto e a organização social. Não necessariamente o número de enterramentos representa o total da população, mas pode indicar uma amostra significativa daquele grupo que recebe formalmente as exéquias. Tal reflexão pode ser aplicada tam-

(3) O catálogo contendo as informações exaustivas dos contextos funerários estudados, assim como o corpo imagético dos mesmos, formam os volumes II e III da tese de doutorado. As análises detalhadas de cada dimensão das práticas mortuárias por sítios e por subperiodos da Idade do Ferro encontram-se nos capitulos 3 e 4 do volume I. As considerações e questões levantadas neste artigo correspondem apenas a um resumo dos pontos tratados na pesquisa. bém para explicar a pequena quantidade de enterramentos infantis em relação ao número de enterramentos de adultos em Argos, Tirinto, Náuplia e Lerna (Tabelas 2 e 3). Se entendermos o SM como um periodo de instabilidade e tensões, as condições de vida devem ter sido abaladas, resultando, provavelmente, em uma taxa elevada da mortalidade de adultos e, particularmente, de crianças. A morte é encarada como um fato comum, recorrente, natural, como parte da vida cotidiana, porém requer métodos de assegurar o retorno seguro dos vivos à vida normal. Dessa forma, a pequena parcela infantil formalizada pelo enterramento pode indicar variações no papel da criança nas comunidades da Argólida. Em Micenas, ela parece assumir um papel mais relevante na sociedade, de inclusão da persona social, comparativamente a Argos, Tirinto, Náuplia e Lerna no mesmo subperiodo. Este papel de inclusão da criança, fundamental para as definições da organização social e política da sociedade, vai se tornando mais evidente no final da Idade do Ferro, principalmente em Argos, quando os enterramentos infantis aumentam, o seu conteúdo torna-se mais variado e localizam-se junto aos enterramentos de adultos, isolados das áreas de habitação.

Examinando os contextos funerários do SM nos sitios selecionados em relação ao atributo tipo de sepultura, notamos que o número de enterramentos em cova simples é elevado, ultrapassando o número de cistas em Argos e Tirinto (Tabelas 4, 5 e 6). Em Micenas e em Náuplia, a cista é o tipo de sepultura característico do SM. Percebemos que as semelhanças nos costumes funerários entre Argos e Tirinto durante o SM são muito maiores quando comparadas com os demais sítios da Argólida. Observa-se que o padrão de sepultamento é o mesmo, tanto os adultos quanto as crianças são enterrados em cistas e covas simples, sendo perceptivel uma preferência nitida pela cista para os enterramentos infantis. Argos é o primeiro sítio a fazer uso dos vasos funerários, especificamente de crateras, para enterrar as crianças, no periodo de transição do SM para o PG. Esta prática funerária é re-introduzida na Idade do Ferro 
Tabela 4

Número total de enterramentos em cista da Idade do Ferro nos sítios da Argólida.

\begin{tabular}{lccccccr}
\hline \hline Sítio / Período & SM & PG & GA & GM & GR & G & Total \\
\hline Argos & 6 & 79 & 53 & 35 & 62 & 84 & 319 \\
Tirinto & 3 & 36 & 13 & 9 & 3 & 3 & 67 \\
Asine & - & 43 & - & - & 5 & - & 48 \\
Micenas & 4 & 8 & 1 & 3 & 6 & - & 22 \\
Naúplia & 4 & - & 1 & 1 & 1 & 1 & 8 \\
Lerna & - & - & - & 12 & - & 6 & 18 \\
\hline & $\mathbf{1 7}$ & $\mathbf{1 6 6}$ & $\mathbf{6 8}$ & $\mathbf{6 0}$ & $\mathbf{7 7}$ & $\mathbf{9 4}$ & $\mathbf{4 8 2}$
\end{tabular}

Tabela 5

Número total de enterramentos em vaso funerário da Idade do Ferro nos sítios da Argólida.

\begin{tabular}{lcccrrrr}
\hline \hline Sítio / Periodo & SM & PG & GA & GM & GR & G & Total \\
\hline Argos & - & 9 & 6 & 7 & 70 & 59 & 151 \\
Tirinto & - & 2 & 6 & 9 & 26 & 11 & 54 \\
Asine & - & - & - & - & - & - & 0 \\
Micenas & - & - & - & 1 & 3 & - & 4 \\
Naúplia & - & - & - & - & 15 & 1 & 16 \\
Lerna & - & - & 2 & 5 & 1 & 7 & 15 \\
\hline & 0 & $\mathbf{1 1}$ & $\mathbf{1 4}$ & $\mathbf{2 2}$ & $\mathbf{1 1 5}$ & $\mathbf{7 8}$ & $\mathbf{2 4 0}$
\end{tabular}

Tabela 6

\begin{tabular}{lcrrrrrr}
\hline \multicolumn{6}{c}{ Número total de enterramentos em cova simples da Idade do Ferro nos sítios da Argólida. } \\
\hline \hline Sítio / Periodo & SM & PG & GA & GM & GR & G & Total \\
\hline Argos & 10 & 23 & 11 & 7 & 11 & 16 & 78 \\
Tirinto & 7 & 5 & 1 & - & 2 & 2 & 17 \\
Asine & - & 17 & - & - & 1 & 3 & 21 \\
Micenas & - & 5 & - & 1 & 1 & 1 & 8 \\
Naúplia & - & 1 & - & - & 1 & 3 & 5 \\
Lerna & - & - & - & - & - & - & 0 \\
\hline & 17 & 51 & 12 & 8 & 16 & 25 & 129
\end{tabular}

como o tipo característico de sepultura para as crianças (Whitley 2001: 94) e, na Argólida, tem origens argivas, difundindo-se ainda, no PG, para Tirinto e, no Período Geométrico, para Lerna, Micenas e Náuplia. É interessante chamar a atenção para o fato de que, aproximando-se do final da Idade do Ferro, o vaso funerário se torna o tipo de sepultura quase que exclusivo dos sepultamentos infantis.

Quando analisamos o conteúdo dos contextos funerários em Argos, Tirinto, Micenas e Náuplia, notamos que, no geral, as cistas e as covas simples apresentam alguns poucos vasos cerâmicos e artefatos em metal, embora haja alguns exemplos de covas simples com grande variedade e quantidade de artefatos em Tirinto e Argos. No entanto, quando comparado com os enterramentos dos demais subperiodos, o mobiliário funerário do SM se apresenta mais modesto, tanto para as crianças quanto para os adultos. Tirinto corresponde ao sítio que contém enterramentos de adultos com mobiliário funerário mais variado no SM e apresenta os casos de reutilização da sepultura 
mais antigos constatados na Argólida, datados do próprio SM.

Finalmente, refletindo sobre as relações entre o espaço dos vivos e o espaço dos mortos, percebemos que há elementos de convergência e distinção entre os sítios. Em Argos, há dois padrões distintos para sepultar os individuos. $\mathrm{O}$ primeiro deles corresponde à deposição dos mortos junto às habitações, não sendo possivel observar a formação de lotes de sepultamentos e nem de áreas exclusivas de deposição dos mortos, isto é, verdadeiras necrópoles. Estes sepultamentos encontram-se bastante dispersos na cidade, nas mesmas áreas onde estão concentrados os vestigios habitacionais, nas áreas Central e Sudoeste da cidade. O segundo padrão é caracterizado pela deposição dos mortos e, principalmente, objetos em uma cova localizada no dromos dos túmulos em câmara micênicos, locais que durante a Idade do Bronze já eram entendidos como necrópoles. Tais ocorrências configuram exemplos de reutilização da sepultura originalmente micênica e podem significar a tentativa dos individuos do SM em estabelecer laços com o passado distante. Tal fato pode ter constituido um recurso importante nas definições dos enterramentos formais dos indivíduos neste periodo que, após um momento de turbulências e mudanças politicas e sociais, ainda estavam sendo estabelecidas. Esta conclusão é reforçada pela presença de objetos de origem micênica nos enterramentos do SM, como, por exemplo, as contas em cristal de rocha e em esteatita dos colares nos sepultamentos argivos e em Tirinto. Em Argos, essa ligação com o passado micênico cessa já no próprio $\mathrm{SM}$, pois constatamos que durante o PG há um processo evidente de reorganização da estrutura social a partir do estabelecimento de novos parâmetros que vão definir uma sociedade estratificada e hereditária, exteriorizada nas práticas mortuárias.

Em Tirinto, a situação é um pouco distinta. Enquanto os vestigios habitacionais estão localizados no interior das muralhas micênicas, os enterramentos do SM encontram-se na área externa, porém estão configurados de uma maneira bastante dispersa, da mesma forma que em Argos. As duas áreas que concentram um número maior de enterramentos do SM são a Área Phylaki e a área a Nordeste da fortificação. Essas duas concentrações podem ser entendidas como pequenos lotes de enterramentos, porém não podem ser classificadas como necrópoles devido à pequena amostragem e à falta de continuidade do uso da área como caracteristicamente funerária.

Em Micenas, os enterramentos do SM estão situados nos mesmos locais dos vestígios habitacionais, na área Sul da Acrópole micênica e, portanto, no interior da fortificação. Todavia possuem um caráter disperso, sem a possibilidade de formação de lotes de enterramentos ou necrópoles. Em Náuplia, os vestígios habitacionais proporcionam um quadro bastante lacunar, entretanto os sepultamentos do SM podem ser caracterizados como casos de reutilização de sepulturas micênicas, assim como acontece em Argos, pois se localizam na área da antiga Necrópole Micênica.

Podemos concluir desse modo que, durante o SM em todos os sítios da Argólida, o espaço dos mortos ainda não pode ser definido como necrópole e, com exceção de Tirinto, nem mesmo forma lotes especificos de enterramentos. No geral, os sepultamentos se configuram de maneira dispersa nos limites da comunidade, na área de ocupação, e estão intimamente relacionados com o espaço dos vivos. Tais características, associadas ao pequeno número de enterramentos e à constituição do mobiliário funerário, denotam que se trata de um periodo de instabilidade que apresenta, de um lado, rupturas e inovações e, de outro, reminiscências. Isto significa que o SM deve ser entendido, portanto, como um periodo transitório entre o Heládico Recente IIIC e o PG (Lemos 2002: 191-193), no qual o novo e o velho convivem e são readaptados na tentativa de estabelecer parâmetros para a configuração de uma nova ordem social.

\section{O Protogeométrico (PG): momento de experimentações}

A primeira caracteristica marcante do PG é evidenciada por um grande aumento do 
número de enterramentos nos grandes sítios da Argólida (Tabela 1). O PG, juntamente com o GR, constitui o subperiodo da Idade do Ferro com a maior quantidade de sepultamentos de adultos e infantis em Argos, Tirinto e Micenas. A situação de Asine é bastante particular, pois os enterramentos são, quase que em sua totalidade, datados do PG. Náuplia só vai apresentar um crescimento significativo dos contextos funerários durante o GR, e Lerna não apresenta enterramentos datados do SM nem do PG; os sepultamentos datam apenas do Periodo Geométrico e apresentam quantidades semelhantes durante o GA, o GM e o GR.

$\mathrm{O}$ aumento no número de enterramentos parece acompanhar um aumento populacional nos principais sitios, indicando que o periodo de maior instabilidade teria cessado e os enterramentos formais teriam alcançado uma maior parcela da comunidade, mesmo que definidos pela execução de práticas mortuárias distintas entre os diferentes grupos sociais. A relativa homogeneidade em relação ao tipo de sepultura e à idade do indivíduo, caracteristica do SM, é substituida por um discreto aumento das diferenças entre os sitios. Verificamos que para Argos, Tirinto, Asine e Micenas a diferença entre a quantidade de enterramentos infantis e de adultos durante o PG é pequena quando comparada aos enterramentos dos demais subperiodos da Idade do Ferro (Tabelas 2 e 3). Isto significa que um maior número de crianças recebe enterramentos formais durante o PG nesses sitios e que, provavelmente, o papel da criança nas comunidades deve ter sofrido modificações em relação ao SM. De um lado, Argos e Tirinto apresentam padrões de enterramento semelhantes durante o PG, pois tanto as crianças quanto os adultos são enterrados em cistas, covas simples e em vasos funerários, havendo uma predominância do uso da cista (Tabela 4). De outro lado, verificamos que em Micenas e Asine não há exemplos de enterramentos em vasos funerários, os indivíduos são sepultados em cistas e em covas simples (Tabelas 4, 5 e 6). Em Micenas, a quantidade de cistas e de covas simples é semelhante e ambos os tipos de sepulturas são usados para as crianças e para os adultos. Em
Asine, constata-se uma preferência evidente pelo uso da cista para as crianças, enquanto os adultos são enterrados tanto em cistas quanto em covas simples.

A maior diferença em relação ao tipo de sepultura do SM para o PG é a introdução do vaso funerário para enterramentos infantis e de adultos. Tal prática de enterramento, a partir do Periodo Geométrico, apresenta um crescimento contínuo em direção ao final da Idade do Ferro e, durante o GR, o vaso passa a ser o tipo de sepultura padrão para enterrar os individuos.

Com exceção de Lerna, que não apresenta enterramentos datados do PG, todos os demais sítios apresentam uma grande quantidade de enterramentos, com mobiliário funerário bastante variado, correspondendo ao subperiodo com a maior concentração desse tipo de sepultamento, tanto para adultos quanto para crianças, em Tirinto e Micenas. O padrão geral verificado para tais enterramentos é a cista. A cova simples no PG apresenta conteúdo bem mais modesto em relação às cistas e, na maioria dos casos, não apresenta oferenda de qualquer natureza. Em Argos, notamos que quase a totalidade dos enterramentos infantis possui mobiliário funerário variado e corresponde a cistas. Já os enterramentos de adultos possuem dois tipos de mobiliário distintos, um caracterizado por cistas com grande variedade de objetos, vasos e metais e, o outro, por enterramentos sem oferendas ou com alguns vasos cerâmicos, correspondentes a cistas, covas simples e alguns vasos funerários. É interessante observar que as cistas variadas do PG são identificadas, na maioria dos casos, a sepultamentos de crianças e de indivíduos do sexo feminino. Todavia, há enterramentos variados de individuos do sexo masculino que já apresentam armamentos, sendo classificados como enterramentos de guerreiros (Courbin 1974: 133-135).

Em geral, todas as cistas de adultos e crianças do PG em Tirinto apresentam-se extremamente variadas e se destacam casos de reutilização da sepultura. Além disso, as crianças enterradas em vasos também apresentam mobiliário mais variado. Em Micenas, a 
concentração de enterramentos infantis variados em cista, no PG, é a maior durante toda a Idade do Ferro, e os adultos em cista também apresentam enterramentos com vasos cerâmicos e artefatos em metal, porém não são tão variados comparativamente àqueles presentes em Argos e em Tirinto.

A partir desse quadro, podemos inferir que, durante o PG, pelo menos em Argos, Tirinto, Micenas e, provavelmente, em Náuplia, o tratamento dado aos mortos em relação ao mobiliário funerário difere bastante em relação ao SM. Uma grande quantidade de crianças recebe enterramentos formais e estes possuem, em sua grande maioria, mobiliário bastante variado. A concentração de enterramentos variados de adultos também é grande, tanto para individuos do sexo feminino, quanto masculino. Portanto, não há uma distinção especifica das práticas mortuárias caracterizada pelo tipo de sepultura, nem pela constituição do mobiliário funerário, fundamentada nos atributos gênero e idade.

Tal fato sugere uma sociedade, no PG, em que o grupo social básico é formado pelo homem, pela mulher e pela criança, porém a criança assume um papel fundamental em relação à constituição da organização social, pois a inclusão da sua persona social está relacionada com as atribuições do status no nascimento e não apenas à riqueza material, reforçando os laços familiares. Além disso, a alta concentração de enterramentos variados indica a formação de uma camada aristocrática com aspectos de uma sociedade guerreira, principalmente em Tirinto e Argos, que busca, através dos laços familiares, se consolidar no poder após o periodo de instabilidades do SM. As sociedades do PG, portanto, principalmente em Argos e em Tirinto, podem ser configuradas como hierárquicas e hereditárias. Para Tirinto ainda é possivel afirmar que esta camada busca laços com o passado micênico, pois ainda constatamos ocorrências de reutilização de túmulos micênicos. Provavelmente esta prática mortuária seja uma forma de legitimar e justificar o status e o poder dessa camada na sociedade que está se organizando. É interessante ressaltar que esta camada faz uso da cista para enterrar seus individuos, enquanto uma camada evidentemente menos abastada, mas que também recebe enterramentos formais, utiliza um outro tipo de sepultura, a cova simples. Neste caso, podemos concluir que o tipo de sepultura está relacionado com as dimensões verticais (status) das práticas mortuárias (McHugh 1999: 51-61).

Asine, como em praticamente todas as outras dimensões das práticas mortuárias, constitui uma exceção também na configuração do mobiliário funerário dos enterramentos do PG. Em primeiro lugar, apesar de uma grande parcela dos enterramentos ser infantil, o padrão de enterramento tanto para os adultos quanto para as crianças é a cista sem oferendas ou com alguns vasos cerâmicos. Há alguns exemplos de cistas com metais ou, ainda, com metais e vasos cerâmicos em pequena quantidade. Entretanto, a grande maioria das covas simples, assim como das cistas, não apresenta artefatos de qualquer natureza. Tal fato pode estar associado às particularidades étnicas e geográficas de Asine. A base da sociedade também parece ter sido a familia nuclear, mulher, homem e criança, caracterizando-se fundamentalmente pela hereditariedade. Todavia, o aspecto hierárquico, expresso tanto pelos laços familiares quanto pelas riquezas materiais neste sitio, não deve ter tido a mesma importância na configuração da sociedade como teve em Argos, Tirinto e Micenas. A sociedade de Asine deve ter tido um caráter mais dinâmico em decorrência do aspecto comercial, de acordo com as caracteristicas geográficas privilegiadas. ${ }^{4}$ Fator este que inclusive explica a ocorrência precoce de elementos áticos na cerâmica em Asine, como o círculo e o semicírculo concêntricos (Papadimitriou 2006: 538).

Quando passamos para a análise dos vestigios habitacionais do $\mathrm{PG}$, constatamos que as evidências ainda são bastante escassas em todos os sítios da Argólida. Entretanto, é possivel observar os primeiros vestígios de oficinas de produção cerâmica, e a relação entre

(4) O assentamento situa-se numa elevação, a colina Barbouna e toda comunidade está totalmente voltada para o mar. 
o espaço dos vivos e o dos mortos torna-se mais produtiva. Em Argos, notamos que há uma continuidade nitida entre as áreas de habitações do SM e do PG. Elas concentram-se nas áreas Sudoeste, Central e Leste da cidade. $\mathrm{Na}$ área Sudoeste foram encontrados vestígios de fornos utilizados para a confecção de vasos cerâmicos (Hägg 1982: 303-306). Além disso, também foram encontrados vestígios de oficinas de produção e até mesmo de um provável local de refinamento de metais (Foley 1988: 80-101). No entanto, apesar da existência precoce de oficinas especializadas de produção artesanal, elas não denotam uma organização comercial complexa. O assentamento, portanto, seria constituido por pequenos núcleos formados por cabanas e construções de pequeno porte espalhadas pelas áreas Sudoeste, Central e Leste (Hägg, 1982: 300).

Os contextos funerários também demonstram uma continuidade no uso das áreas do SM para o PG, porém apresentam uma expansão. Os enterramentos estão concentrados em três grandes áreas de Argos, Centro-Leste, Oeste-Sudoeste e Norte-Nordeste. Cada área possui uma quantidade similar e substancial de sepultamentos, não apresentando distinções em relação ao tipo de sepultura e nem ao atributo idade. É interessante notar que os enterramentos estão situados próximos às áreas de habitação e ainda possuem um caráter disperso, mas não são isolados. Começam a aparecer os primeiros agrupamentos de sepulturas, formando lotes de enterramentos que denotam claramente a existência de um grupo aristocrático fundamentado em laços familiares, contudo não é possivel indicar com nitidez a formação de necrópoles.

Em Tirinto, o padrão de assentamento no interior das muralhas micênicas parece se manter durante o PG. Além disso, vestigios de uma construção sagrada, denominada templo, contendo vários fragmentos cerâmicos, foram encontrados sobre as ruínas do mégaron do Palácio Micênico (Foley 1988: 26). Não foram encontrados vestigios de oficinas ou ateliês de produção cerâmica datados do PG no sítio. Entretanto, alguns vestigios de habitações começam a ser encontrados na área externa da fortificação micênica, principalmente na área Nordeste, indicando a presença de pequenos aglomerados rurais (Papadimitriou 1998: 125 126, 2006: 545).

As áreas de concentração de enterramentos do PG, em Tirinto, estão localizadas na parte externa, no entorno da muralha micênica. Observam-se quatro grandes áreas de concentração de sepulturas: na denominada Seção Oeste da Cidadela (Stadt-West), com uma grande quantidade de enterramentos; na Necrópole Sudoeste; na Área Phylaki; e a Nordeste da Cidade Baixa. Estas grandes áreas obtêm, desde o PG, um caráter mais especifico de espaço reservado aos mortos, formando as primeiras necrópoles em Tirinto, que, aliás, serão utilizadas de forma ininterrupta até o final da Idade do Ferro. A Área a Nordeste da Cidade Baixa pode ser entendida como uma necrópole especifica dos grupos rurais que habitavam as proximidades (Papadimitriou 1998: 125-126). Não é possivel identificar lotes de enterramentos classificados de acordo com os atributos tipo de sepultura e nem idade, porém, já no PG, observa-se o início da delimitação de espaços dos mortos em relação ao espaço dos vivos.

Asine, distintamente dos demais sitios, apresenta uma quantidade significativa de vestigios habitacionais datados do PG. As habitações possuem formato absidal e quadrangular, e estão situadas na área da Cidade Baixa, na Acrópole e na encosta da Colina Barbouna (Wells 1983: 29-30). Da mesma forma que o registro habitacional, os contextos funerários também são abundantes em Asine e estão concentrados nas mesmas áreas onde se localizam as habitações. As sepulturas de adultos e de crianças situadas na área da Cidade Baixa estão bem próximas e possuem a mesma orientação que os edifícios habitacionais, denotando a formação de lotes familiares.

Em Micenas, os vestigios habitacionais do PG estão localizados fundamentalmente no interior da Cidadela micênica, nos mesmos locais onde foram encontradas habitações do SM, na parte Sul e também na parte Oeste da Acrópole. Também não foram identificados 
vestígios de ateliês cerâmicos em Micenas do PG. Os enterramentos deste subperiodo estão localizados na área interna da fortificação, junto das áreas habitacionais, e em uma outra concentração na área externa da Acrópole, principalmente na área da Casa dos Escudos. $\mathrm{O}$ número de enterramentos é pequeno para permitir reflexões mais aprofundadas em relação à formação de necrópoles e lotes especificos de enterramentos, mas podemos afirmar que se trata de um periodo de transição, em que os enterramentos, antes com um caráter bastante disperso e isolado, começam a se agrupar, de um lado, nas proximidades das habitações e, de outro, em áreas mais afastadas, configurando o início da formação de futuras necrópoles. Entretanto, não é possivel constatar a presença de lotes configurados a partir do quesito tipo de sepultura e nem de acordo com o elemento idade.

Náuplia apresenta vestigios habitacionais e funerários bastante escassos durante o PG. Contudo, o único enterramento do subperiodo está localizado na área que será utilizada especificamente para enterramentos no Geométrico, principalmente durante o GR, no Terreno Pronoia.

Podemos concluir, dessa maneira, que o PG caracteriza-se por um periodo em que as primeiras áreas exclusivas de deposição dos mortos começam a ser delineadas em todos os sítios da Argólida, com possibilidades de identificação de lotes familiares e/ou configurados a partir do status de um determinado grupo. Tal processo se desenvolve, em maior e menor grau, de acordo com o sítio. Em Argos, Micenas e Náuplia, os enterramentos ainda possuem um caráter mais disperso, apesar de apresentarem, em determinadas áreas, a formação de lotes de enterramentos. Já em Tirinto e em Asine, tal processo é evidenciado de forma mais clara e precisa.

\section{O Geométrico Antigo (GA): a formação de uma nova ordem social}

Uma caracteristica que nos chama a atenção durante o GA é a queda substancial do número de enterramentos em Argos, Tirinto, Asine, Micenas e Náuplia (Tabela 1). Em Asine, o declínio é abrupto, mas Lerna começa a apresentar enterramentos da Idade do Ferro somente durante o GA. Percebemos que há uma queda geral na utilização da cova simples nos principais sítios da Argólida (Tabela 6). Em Argos e Tirinto, os três tipos de sepultura são utilizados para enterrar adultos e crianças, mas observa-se uma diferença relevante entre os dois sítios. Em Argos, a cista ainda é majoritária e, em seguida, destacam-se os enterramentos em covas simples, embora a quantidade de vasos funerários seja similar à de covas simples. Em Tirinto, a cista e os vasos funerários são usados em quantidades semelhantes para a grande maioria dos enterramentos, e a cova simples quase desaparece (Tabelas 4, 5 e 6). Além disso, a partir do GA, as crianças passam a ser sepultadas exclusivamente nos vasos funerários, essencialmente em pitos e ânforas.

Em Micenas, Náuplia e Lerna, a cista permanece como o tipo de sepultura padrão para os adultos. As crianças em Micenas também são enterradas nas cistas durante o GA, enquanto em Lerna, é neste subperiodo que se dá a introdução do vaso funerário para os enterramentos infantis, mas as cistas ainda são dominantes. Os enterramentos infantis em Náuplia só aparecem no GR e, durante o GA, os adultos também são enterrados em covas simples, porém em um número bastante reduzido quando comparado às cistas.

Quando examinamos o conteúdo dos contextos funerários do GA em Argos, Tirinto e Micenas, percebemos que, no geral, há uma certa continuidade do padrão verificado no PG, definido pelas cistas com oferendas mais variadas e as covas simples com oferendas mais modestas. Notamos que em Argos há até mesmo um aumento evidente da ostentação nos enterramentos de adultos. Durante esse subperiodo, não há exemplos de enterramentos sem oferendas, todos os adultos são sepultados com vasos cerâmicos e, principalmente, com artefatos de metal. Tal ostentação é marcante nos enterramentos de adultos que serão, na grande maioria dos casos, reutilizados durante o GM e o GR. 
Em Tirinto, a situação é um pouco distinta, pois a quantidade de enterramentos com mobiliário funerário mais variado sofre um leve declínio. Entretanto, as cistas variadas ainda são numerosas, e começam a aparecer enterramentos de adultos em vasos funerários com artefatos mais diversificados, principalmente metais, tendência que vai ser mantida no GM e reforçada no GR. Micenas apresenta um quadro bastante semelhante ao argivo, pois as cistas infantis e de adultos contêm oferendas bastante variadas, enquanto as covas simples correspondem a enterramentos bem mais modestos. Em Náuplia e Lerna, apesar da pequena quantidade de enterramentos, a maioria não possui oferendas, e o número de enterramentos com mobiliário funerário diversificado é pequeno, não só durante o GA, mas em toda a Idade do Ferro, e tende a se concentrar no GR.

Os vestígios de ocupação do Periodo Geométrico são mais evidentes e abundantes em relação aos subperiodos anteriores. Em Argos, notamos que as áreas de habitações do SM e do PG passam a ser utilizadas apenas para enterramentos. Da mesma forma que no PG, a área Centro-Leste apresenta a maior quantidade de enterramentos, indicando um processo claro de continuidade de uso do espaço para deposição dos mortos entre o PG e o GA. Além disso, esta área, juntamente com a área Sudoeste, abriga a maioria das cistas variadas de adultos, tanto do PG quanto do GA. São estas mesmas cistas do GA que apresentam enterramentos múltiplos, sendo reutilizadas durante o GM e, principalmente, o GR. Muitas delas, quando não foram reutilizadas, apresentam um série de vasos cerâmicos datados do GR depositados sobre as placas de cobertura da cista.

O processo de organização da sociedade argiva, iniciado no PG, é consolidado durante o GA, com a formação de uma sociedade guerreiro-aristocrática estratificada fundamentada no nascimento. Esta camada exterioriza seu poder e status através dos enterramentos em cistas. As covas simples podem indicar a presença de uma camada menos abastada que cada vez mais, conforme se aproxima do final da Idade do Ferro, perde espaço nas instâncias do poder e do social. Ainda podemos concluir que o processo de separação entre o espaço profano e o funerário, iniciado no PG, se acentua durante o GA, pois as áreas de concentração de enterramentos são mantidas, enquanto as áreas habitacionais se afastam, sem se isolarem totalmente.

Em Tirinto, os vestigios de habitações, muros e pavimentos e fragmentos cerâmicos, datados desde o GA até o GR, localizam-se tanto no interior da fortificação quanto na área externa das muralhas, principalmente a Oeste da Cidadela, próximo da área funerária. Em 2001, a campanha de escavação dirigida por J. Maran e A. Papadimitriou revelou o primeiro ateliê cerâmico em Tirinto, datado do início do Periodo Geométrico e localizado na área Nordeste da Cidade Baixa (Maran; Papadimitriou 2006: 97-169). Notamos, dessa forma, que a ocupação no interior da Cidadela micênica não cessa durante o Periodo Geométrico, principalmente durante o GA. Todavia, observamos um movimento de ocupação inverso, através do qual as áreas de habitação começam a se expandir para fora dos limites da fortificação, a Oeste, nas proximidades dos locais onde se situam as áreas de concentração de enterramentos.

Estas áreas de concentração localizam-se nos mesmos locais dos sepultamentos do PG. A variedade e a quantidade dos artefatos depositados nas cistas do GA diminuem em relação àquelas datadas do $\mathrm{PG}$, mas os enterramentos em vasos funerários passam a apresentar um mobiliário funerário mais diversificado, constituido principalmente por artefatos de metal. Não é possivel identificar lotes especificos de enterramentos classificados segundo o tipo de sepultura e nem de acordo com o atributo idade, pois os três tipos de enterramentos, tanto de adultos quanto de crianças, são encontrados em todas as áreas de concentração. Contudo, da mesma maneira que em Argos, o processo de separação do espaço dos vivos e do espaço dos mortos é intensificado neste subperiodo. Além disso, observamos em Tirinto um outro processo de especialização do espaço e das atividades comerciais, com o estabelecimento das primeiras oficinas de produção cerâmica. Apesar de constituir uma 
comunidade menor em relação à argiva, Tirinto se destaca desde o início da Idade do Ferro no desenvolvimento de atividades artesanais próprias e na configuração de áreas exclusivas para deposição dos mortos.

O mesmo processo de expansão das áreas habitacionais para o exterior da Acrópole é verificado em Micenas. Entretanto, a área interna do Palácio micênico continua sendo intensamente ocupada com construções habitacionais e sagradas. Os enterramentos concentram-se todos na área externa da fortificação. Observamos, dessa maneira, que o processo de expansão dos enterramentos para fora dos limites da Cidadela, iniciado no PG, é consolidado durante o GA. As áreas de concentração do PG continuam sendo utilizadas para a deposição dos mortos e, portanto, podemos perceber que em Micenas também há uma intensificação do processo de especialização do espaço dos mortos, mesmo que localizado nas proximidades de áreas residenciais. A área interna da Acrópole micênica, a partir do GA, torna-se um espaço exclusivamente habitacional e sagrado, uma vez que deste subperiodo em diante não são mais encontrados enterramentos no interior da muralha.

Em Náuplia, os vestigios habitacionais e também os funerários, datados do GA, são bastante escassos e lacunares. Todavia, parece haver uma continuidade do uso da área de concentração de sepultamentos do PG para o GA, que será utilizada durante o GM e, de maneira mais intensa, durante o GR, como área exclusiva de deposição dos mortos. Lerna é marcada por uma ausência de vestigios habitacionais durante toda a Idade do Ferro. Os enterramentos se localizam em importantes e abundantes vestigios habitacionais do Heládico Médio e do Heládico Recente. Durante todo o Periodo Geométrico, a área passa a abrigar apenas enterramentos. Náuplia e Lerna devem ter sido comunidades de pequenas proporções durante toda a Idade do Ferro, caracterizadas por instabilidade e profunda influência argiva e de Tirinto.

O GA constitui, desse modo, um periodo de suma importância no processo de consolidação da sociedade guerreiro-aristocrática hierarquizada argiva, que também encontra as origens de sua hegemonia nos demais sítios da Argólida. Entretanto, Tirinto, de forma mais acentuada, e também Micenas, apresentam caracteristicas que denotam certa independência e competitividade em relação à supremacia argiva. Tirinto inclusive desenvolve ateliês próprios. Náuplia e Lerna se caracterizam pela presença de influências argiva e de Tirinto. Notamos ainda uma intensificação generalizada do processo de separação do espaço dos vivos das áreas funerárias.

\section{O Geométrico Médio (GM): intensifica-se a ostentação}

O GM é configurado por uma nova queda no número total de enterramentos de adultos e de crianças em Argos (Tabelas 2 e 3). Tirinto, Asine, Micenas, Náuplia e Lerna, inversamente, voltam a apresentar um crescimento, mesmo que moderado. Uma caracteristica marcante deste subperiodo, para todos os sítios, com exceção de Asine, é o aumento do uso dos vasos funerários para enterrar os individuos (Tabela 5). Em Argos, a cista ainda é majoritariamente utilizada para enterrar adultos e crianças, porém o número de covas simples diminui, sendo superado pela quantidade de enterramentos em vasos funerários. Em Tirinto, os vasos e as cistas são utilizados em quantidades semelhantes, mas as crianças são enterradas exclusivamente nos vasos e, dessa forma, nota-se que ainda há uma preferência por enterrar os adultos nas cistas, da mesma forma que em Argos. Entretanto, a cova simples não é utilizada nos enterramentos em Tirinto neste subperiodo (Tabela 6).

Micenas apresenta um quadro similar ao argivo, sendo utilizados os três tipos de sepultura para enterramentos de adultos e infantis, com primazia pelo uso da cista, seguida do vaso funerário e, finalmente, da cova simples. Náuplia, apesar da pequena quantidade de enterramentos datados do GM, pode ser caracterizada como uma exceção, pois não apresenta enterramentos em vasos funerários, mas apenas os de adultos em cistas e covas simples. Este fato pode estar relacionado com a 
ausência de enterramentos infantis no sítio desde o SM. As crianças só aparecem, em Náuplia, no GR e são enterradas exclusivamente em vasos. Tal aspecto reforça a hipótese da adoção do uso do vaso funerário como o tipo de sepultura originalmente destinado aos enterramentos infantis.

A configuração do mobiliário funerário, durante o GM, reforça a ideia da competitividade inter-sítios. Em Argos, o padrão de ostentação das cistas do GA, principalmente dos adultos, é mantido, e verificamos um aumento na quantidade de enterramentos variados. Micenas assemelha-se ao padrão argivo, com o crescimento das cistas com mobiliário funerário mais variado para os enterramentos de adultos. Tirinto, além das cistas diversificadas de adultos, apresenta um grande número de pitos que contém principalmente artefatos em metal. É interessante notar que, ainda no GM, são encontrados objetos de origem micênica nos contextos funerários. Esta prática indica que os habitantes de Tirinto buscam estabelecer laços com os antepassados da Idade do Bronze. Náuplia e Lerna possuem muito poucos enterramentos datados do GM, da mesma forma que Asine, mas ainda tendem a seguir o padrão argivo, apresentando cistas com conteúdo mais variado em relação aos demais tipos de sepulturas.

No final do GM podemos observar um processo de rápido crescimento das áreas habitacionais, dos ateliês, de estruturas com possiveis funções rituais e também do número de sepulturas em todos os sitios da Argólida. Em Argos, na área Sudoeste, foram encontrados vestígios de muros que indicam a presença de habitações e, na área Central, uma outra construção orientada no sentido Leste-Oeste também denota a presença de habitações no local, onde também foram encontradas sepulturas em cista alinhadas com a construção, no sentido Leste-Oeste (Hägg 1982: 305). Tais sepulturas denotam a presença de um grupo social destacado, pois todos os enterramentos presentes nesta área são de adultos em cistas, com mobiliário funerário bastante variado, sendo dois deles reutilizados. Os enterramentos do GM apresentam uma relação evidente de continuidade com as áreas de concentração do GA. Apesar da queda do número total de enterramentos (Tabela 1), observamos que o processo de ostentação do mobiliário funerário das cistas se intensifica, com a presença de túmulos de guerreiros, com armamentos em bronze e em ferro, principalmente na área SulSudoeste e Central de Argos. Muitos destes túmulos são reutilizados durante o GR e, além disso, apresentam uma grande quantidade de vasos cerâmicos datados do GR depositados sobre as placas de cobertura das cistas. Percebemos, portanto, que durante este periodo as áreas habitacionais permanecem próximas das sepulturas, embora o processo de estabelecimento de áreas com propósitos exclusivamente funerários e definidas por laços familiares e/ou sociais torna-se mais nitido. Processo este que é concluído durante o GR, formando necrópoles propriamente ditas.

Em Tirinto também observamos uma queda no número total de enterramentos e os vestigios habitacionais não são abundantes, contudo permanecem nos mesmos locais onde foram encontrados os vestigios do GA, concentrando-se na área externa da Cidadela. Durante o GM, a Necrópole Sudoeste e a Área Phylaki passam a apresentar a maior quantidade de enterramentos e é possivel identificar com mais clareza a formação de lotes familiares dentro das próprias áreas de concentração de enterramentos, como por exemplo, a presença de um conjunto de enterramentos infantis datados do GM e do GR na Necrópole Sudoeste. O processo de ostentação da camada guerreiro-aristocrática, em Tirinto, é um pouco diferenciado do argivo, pois os enterramentos em vasos funerários de adultos e infantis apresentam oferendas em metal, principalmente.

Em Asine, os vestigios habitacionais do GM se concentram na área da Cidade Baixa e indicam um crescimento e intensificação da ocupação do sítio, inversamente aos dados revelados pelos enterramentos. Nessa área há vestigios de habitações e construções, principalmente de formato absidal e quadrado, que parecem indicar funções sagradas. Em Micenas, as evidências habitacionais e de estruturas sagradas permanecem mais restritas à área 
interna da fortificação, nas porções Oeste e Sul da Acrópole. A quantidade total de enterramentos também diminui no GM, porém o processo de separação do espaço dos vivos e dos mortos é reforçado, uma vez que a concentração dos enterramentos localiza-se na área externa da Cidadela micênica. Contudo, não é possivel identificar de forma tão explicita a formação de lotes. Em Náuplia, tanto os vestigios habitacionais quanto os funerários são bastante escassos durante o GM, entretanto parecem manter o padrão verificado no GA e no PG, através do qual os enterramentos situam-se nas proximidades das residências. Lerna, apesar da ausência de vestígios habitacionais, apresenta um aumento no número de enterramentos na área de concentração originalmente do GA. O padrão de enterramento parece assemelhar-se mais ao argivo, com intensificação do uso de vasos funerários, principalmente do pito, sem a presença de oferendas. Contudo, alguns pitos com sepultamentos de adultos apresentam mobiliário funerário bastante variado.

Podemos concluir que, durante o GM, o processo de ostentação nas sepulturas é intensificado de forma acentuada, principalmente em Argos, e sua influência na planície aumenta. Entretanto, Tirinto, Asine e Micenas parecem conservar traços que definem uma certa independência. As áreas de enterramento vão adquirindo cada vez mais um caráter especializado, apesar de não ser possivel a identificação de necrópoles propriamente ditas. Contudo, a formação de lotes exclusivos de enterramentos familiares/sociais já é claramente perceptivel em Argos, Tirinto e Micenas.

\section{O Geométrico Recente (GR): renascimento ou reafirmação?}

O Geométrico Recente constitui o subperiodo da Idade do Ferro em que as transformações evidenciadas desde o $\mathrm{PG}$, mas principalmente no GA e no GM, se consolidam e alcançam o grau máximo de maturidade, no que diz respeito às práticas mortuárias. As mudanças ocorridas no século VIII a.C., que levam ao processo de consolidação da pólis argiva, portanto, devem ser entendidas não como inovações e singularidades inusitadas, mas sim como tendências já existentes e manifestadas desde, pelo menos, o início do século IX a.C. Durante o século VIII, principalmente na segunda metade, tais elementos sofrem um processo de crescimento acelerado. Um dos elementos mais visiveis desse processo de crescimento é o notável aumento da quantidade de enterramentos, principalmente em Argos, Tirinto, Micenas e Náuplia (Tabela 1). Percebemos que há uma certa homogeneização das práticas funerárias em relação aos quesitos idade e tipo de sepultura nos sítios da Argólida neste subperiodo, com exceção de Asine. A tendência geral em relação ao tipo de sepultura utilizada durante o GR é a utilização do vaso funerário, principalmente para enterramentos infantis, mas também para enterramentos de adultos. $\mathrm{O}$ número de vasos funerários utilizados cresce vultuosamente, chegando até mesmo a ultrapassar o número de cistas em Argos, Tirinto e Náuplia (Tabelas 4 e 5). Em Micenas e Lerna, as quantidades desses dois tipos de sepulturas são semelhantes. Em Argos, Tirinto, Náuplia e Lerna, as crianças são enterradas exclusivamente em vasos funerários no GR. Micenas ainda apresenta alguns exemplos de enterramentos infantis em cista. A cova simples é raramente utilizada em todos os sitios, principalmente para as crianças (Tabela 6).

Em Argos, o padrão para enterrar as crianças é a utilização da cratera, enquanto nas demais comunidades, é o pito, embora a ânfora também apareça em grande número nos sepultamentos infantis. $O$ pito corresponde a um vaso manufaturado de grandes proporções e que apresenta decoração incisa ou apliques. Já as crateras e ânforas são torneadas e apresentam motivos ornamentais bastante variados, inclusive figurados típicos da produção cerâmica argiva do GR, como os cavalos, as aves e as representações de figuras humanas.

As maiores diferenças entre os sitios dizem respeito aos enterramentos de adultos. Em Argos e Micenas, a maioria dos adultos é enterrada em cistas, enquanto em Tirinto e Náuplia o padrão de enterramento dos adultos segue o das crianças e, portanto, uma parcela 
vultosa dos adultos é enterrada em pitos. Lerna apresenta poucos enterramentos datados do GR, contudo parece seguir o padrão verificado em Tirinto e Náuplia. Durante o GR, notamos que, mesmo nos sitios em que o número total de enterramentos infantis é muito inferior ao total de sepultamentos de adultos, como Argos, Tirinto, Náuplia e Lerna, a diferença entre eles diminui, da mesma forma que durante o PG (Tabelas 2 e 3). Este fato nos remete novamente à questão da inclusão das crianças nas práticas mortuárias e, portanto, proporcionam reflexões sobre os papéis e a importância de sua persona social nas sociedades da Argólida.

Percebemos que em todos os sítios a concentração de enterramentos com mobiliário funerário mais variado é grande, tanto para as crianças quanto para os adultos. Observamos três configurações distintas entre os sitios no que diz respeito à análise do mobiliário funerário, relacionado com os atributos idade e tipo de sepultura. Uma delas é definida pelos enterramentos de adultos em Argos, Micenas e Náuplia, que correspondem a cistas com artefatos bastante diversificados. A segunda, para os enterramentos de adultos e de crianças, é caracterizada pelos enterramentos em vasos funerários sem a presença de oferendas, verificada em Argos e em Náuplia. A terceira corresponde aos enterramentos de adultos e infantis também em vasos funerários, principalmente em pitos, com mobiliário funerário mais variado, seja composto por vasos cerâmicos e metais ou apenas por artefatos em metal. Tal padrão é constatado em Tirinto, Micenas e Lerna. Nestes sitios, as cistas do GR apresentam um mobiliário funerário mais modesto, processo radicalmente inverso ao argivo. Em Tirinto, todos os enterramentos infantis em vasos possuem oferendas mais diversificadas.

Em Argos, à primeira vista, os enterramentos estariam divididos em duas grandes categorias: as cistas variadas e os pitos sem oferendas. Entretanto, examinando os enterramentos de forma mais cautelosa, notamos que os enterramentos infantis, na grande maioria em vasos funerários, não apresentam oferendas, principalmente aqueles em crateras e ânforas. Os pitos apresentam, muitas vezes, algum tipo de oferenda, essencialmente vasos cerâmicos. Os enterramentos de adultos em cistas apresentam artefatos bastante diversificados, principalmente em metal, e caracterizados pela presença de armamentos em enterramentos de individuos do sexo masculino. Os pitos utilizados para os adultos, na grande maioria dos casos, não possuem oferendas, porém há alguns deles que são extremamente variados. É essencial ressaltar que, mesmo sem a presença de objetos, os vasos funerários do GR são de grande porte e possuem algum tipo de ornamentação.

Está evidente que em Argos, durante o GR, o processo de ostentação daquela camada guerreiro-aristocrática, que tem suas origens no GA, intensifica-se, muito provavelmente devido às transformações que levam à consolidação da pólis argiva. As crianças voltam a possuir um papel fundamental na constituição da sociedade, pois reforçam os laços familiares, legitimando e justificando o status e o poder de um grupo. Tais reflexões são fortalecidas com a análise da localização das sepulturas e devido ao grande número de reutilizações de sepulturas durante o GR. Uma parcela significativa dos enterramentos múltiplos corresponde a cistas de adultos datadas originalmente do GA e do GM, reutilizadas no GR.

Os vestigios de ocupação do GR na maioria dos sitios examinados e, principalmente, em Argos, tornam-se abundantes o suficiente para afirmar que, a partir da segunda metade do século VIII a.C., a comunidade adquire aspectos de uma verdadeira pólis, caracterizada por uma expansão significativa das atividades comerciais e artesanais. R. Hägg afirma que já no final do GM II pode ter havido um processo de synoikismós ${ }^{5}$ interno no assentamento, responsável pelo agrupamento dos pequenos núcleos rurais e das propriedades comerciais e artesanais, formando a pólis argiva durante $\mathrm{o}$ GR (Hägg, 1982: 302). Percebemos que as áreas

(5) Do grego бuvoıкı $\sigma$ ó que significa coabitação, fusão, estar reunido em uma cidade. Trata-se do processo de agregação das comunidades gregas, levando à constituição da pólis. Em português, é tradicionalmente denominado sinecismo. 
de enterramentos ainda continuam próximas das concentrações habitacionais, porém, durante o GR, tornam-se mais densas e isoladas, formando lotes de sepultamentos.

As áreas de concentração de enterramentos do GR, em Argos, correspondem às áreas SulSudoeste, Central e Noroeste. Estes locais, principalmente a área Sul-Sudoeste e a Central, correspondem às mesmas regiões utilizadas desde o SM, com intensificação do uso no PG, no GA e no GM. Não é possivel verificar uma distinção entre os as áreas de enterramentos de acordo com o atributo idade e nem a partir da dimensão tipo de sepultura. Os adultos e as crianças e os três tipos de sepultura são encontrados nos mesmos locais. No entanto, há evidências nitidas de lotes familiares definidos por tipos de sepultura, como o grupo de pitos na área Centro-Leste e dois grupos de cistas, um deles localizado na área Sul-Sudoeste e o outro na área Noroeste. Tais enterramentos denotam a presença de uma camada guerreiroaristocrática, fundamentada em laços familiares, que busca legitimar seu poder e seu status no final da Idade do Ferro. Tal ideia encontra ainda respaldo na prática de deposição de vasos sobre as sepulturas datadas do GA e GM. Tais incursões indicam que determinados grupos do GR buscam reafirmar laços familiares com seus antepassados da própria Idade do Ferro.

O processo de formação da pólis argiva envolve, portanto, uma sociedade complexa que está em processo de transformação, mas que tem suas raizes fundamentadas em uma sociedade guerreiro-aristocrática hierarquizada e cujo poder é atribuído ao nascimento. Esta sociedade teria se formado ainda no PG e se consolidado no GA. Isto não significa dizer que tal processo é semelhante ao Ateniense, em que haveria "cemitérios de cidadãos" (Morris 1987: $54,210)$ como simbolos garantidos de direito políticos e acesso a propriedade (Saxe 1970: 119). A complexidade dos enterramentos do GR revela que o processo de consolidação da pólis argiva abrange mais do que as duas categorias sociais propostas por R. Hägg formadas pelos ricos de um lado, utilizando a cista para os enterramentos e os pobres fazendo uso do pito para enterrar seus membros, de outro (Hägg 1974: 133-134, 147-149; 1980: 125 126; 1983: 30-31; 1998: 134).

Os enterramentos em vasos funerários, sejam pitos ou crateras e ânforas, não devem ser entendidos como uma correspondência direta de uma prática de enterramento executada por um grupo menos abastado da sociedade. Alguns apresentam mobiliário funerário bastante variado e decoração ricamente elaborada. Isto indica que devem ter sido objetos de grande valor, já que o esforço e o investimento para a confecção do vaso são elevados. Além disso, notamos que os enterramentos múltiplos correspondem, na grande maioria dos casos, a cistas. Tal tipo de sepultura também possui um alto investimento no processo de elaboração. Contudo, verificamos que, durante o GR, apesar do aumento das dimensões das cistas, não são construidas novas cistas para cada individuo, indicando que, apesar do trabalho de reabertura da cista, não há um investimento e nem um grande dispêndio de energia no processo de edificação do túmulo, quando comparados às inumações individuais em cista. A grande maioria dos vasos funerários do GR contém inumações individuais e, desse modo, podem denotar um investimento maior desse grupo na realização das práticas funerárias. Quando os vasos apresentam decoração, podemos afirmar que não somente a variedade e a qualidade de motivos ornamentais geométricos e figurativos são elevadas, mas também seu repertório pertence às mesmas caracteristicas guerreiro-aristocráticas do repertório iconográfico encontrado nos vasos presentes nas cistas.

O exame dos enterramentos em covas simples, contudo, fornece um quadro diferenciado. Este tipo de sepultura é menos numerosa durante o GR (Tabela 6) e a grande maioria não apresenta oferendas ou, quando algum conteúdo está presente, corresponde a uma quantidade e qualidade de artefatos muito mais modestas em relação àquelas que caracterizam as cistas. Tais fatos podem ser explicados pelo elemento visibilidade, pois esse grupo de individuos estaria recebendo uma quantidade cada vez menor de enterramentos formais aproximando-se do final da Idade do Ferro. Estudos osteológicos dos enterramentos em 
cista e em cova simples de adultos ${ }^{6}$ corroboram $^{2}$ tal hipótese, pois os individuos sepultados nas covas simples apresentam uma quantidade maior de doenças que estão diretamente relacionadas, de um lado, às atividades cotidianas e, de outro, à dieta alimentar dos individuos. As doenças desses individuos são configuradas por infecções, traumas e doenças metabólicas e denotam, no geral, condições mais precárias de vida, como a exposição a práticas cotidianas de trabalho mais árduas e a uma dieta mais pobre e deficiente, indicando, assim, um status social inferior.

Dessa forma, percebemos uma nitida estratificação na sociedade que, através das práticas mortuárias, exterioriza seus interesses e anseios sociais em um momento em que as transformações politicas estão se acentuando. Podemos inferir, então, que no século VIII a.C. Argos caracteriza-se como uma comunidade de grandes proporções e potencialmente hegemônica que tende a intensificar sua influência sobre as demais sociedades na Argólida, visando expandir seu domínio na planície. Este processo é evidenciado não só pelas práticas funerárias, mas também pelos vestigios arquitetônicos. A construção do Heraion argivo por volta de 725 a.C. a $8 \mathrm{~km}$ de Argos e próximo de Micenas, Berbati e Dendra pode ser entendida como uma tentativa de Argos de estender seu território e aumentar sua influência e dominação sobre as demais comunidades da Argólida. A tentativa de adoção de um culto comum significa, na realidade, a expressão da diplomacia agressiva argiva (Morgan e Whitelaw 1991: 84-85). É nesse sentido que compreendemos as

(6) Estudos osteológicos para o material ósseo das escavações francesas vêm sendo conduzidos pela antropóloga fisica L. Hapiot, e o das escavações gregas, por M. P. Richards, S. Voutsaki, S. Triantaphyllou, S. Kovatsi, entre outros, através de análise de DNA e de isótopos estáveis de carbono e nitrogênio nos esqueletos. Tais estudos envolvem uma análise detalhada do material ósseo que considera outras partes essenciais do esqueleto humano para a definição de idade, gênero, dieta, doenças e etnia. Agradecemos E. Pappi e L. Hapiot pelo fornecimento de informações sobre tais estudos inéditos, realizados a partir de uma significativa amostragem do material ósseo proveniente dos túmulos do Periodo Geométrico. destruições dos sitios, seja de Asine, ainda no final do século VIII a.C., seja de Micenas e Tirinto, no século $\mathrm{V}$ a.C.

O exame dos vestigios habitacionais de Tirinto indica que o processo de ocupação habitacional ao redor da fortificação sofre um processo de intensificação na área Oeste e Sul. Este fenômeno também é verificado na distribuição dos enterramentos. As áreas de concentração de enterramentos são essencialmente a Necrópole Sudoeste e a Área Phylaki. Os exemplos de covas simples são raros e os vasos funerários são majoritários, porém todos eles são encontrados nas duas áreas de concentração e são caracterizados tanto por enterramentos infantis quanto de adultos. Entretanto, podemos constatar a existência de lotes familiares e sociais de enterramento que são formados desde o GM.

É importante ressaltar que esses lotes familiares/sociais em Tirinto possuem algumas características distintas em relação aos argivos, indicando que o processo de ostentação da camada guerreiro-aristocrática no sítio se deu de uma forma peculiar. Os enterramentos em pitos, de adultos e, principalmente, de crianças, são mais variados que as cistas nesse subperiodo, contendo particularmente objetos em metal. Tais peculiaridades reforçam a ideia de competitividade entre os sitios nesse momento. Entretanto, é dificil classificar Tirinto como uma pólis, pois as evidências arqueológicas não revelam o crescimento da comunidade como uma área comercial e artesanal do mesmo porte que Argos. Está claro que a comunidade atinge um grande crescimento no GR, ultrapassando o status inicial verificado no PG de áreas rurais isoladas, e certamente constituiu a segunda maior comunidade da região. Todavia, o sitio ainda continua sobre fortes influências argivas, tanto no âmbito cultural (inclusive religioso) quanto politico. Tais reflexões se relacionam também com a própria localização geográfica do sítio na planície, situado a apenas $6 \mathrm{~km} \mathrm{a}$ sudeste de Argos.

Micenas, no que diz respeito aos vestigios habitacionais, mantém o padrão de assentamento verificado no GA e no GM. As residências, compostas fundamentalmente por cabanas 
e vestígios de construções com funções rituais, concentram-se na área interna da Acrópole micênica. Em relação às áreas funerárias, percebemos que há continuidade de uso das mesmas áreas do GM. O processo de ostentação das cistas dos adultos também é verificado nesse sítio e se soma a uma certa ostentação dos enterramentos infantis em pitos, que também apresentam mobiliário funerário mais diversificado. Não é possivel visualizar de forma tão nítida, em Micenas, a constituição de lotes familiares/sociais. Mesmo durante o GR, a comunidade em Micenas não deve ter atingido grandes proporções e, até o momento, não há vestigios que confirmem a existência de comércio e artesanato de grande porte.

Asine mostra-se um sitio independente desde o início da Idade do Ferro em todos os sentidos e, apesar de não apresentar uma camada guerreiro-aristocrática tão nítida quanto a argiva, ou até mesmo em relação àquela evidenciada em Tirinto e em Micenas, constitui o sítio mais excêntrico da Argólida, com caracteristicas sócio-culturais e étnicas próprias. ${ }^{?}$ Durante o GR, apesar da escassez dos registros funerários, os vestigios habitacionais são significativos. Há evidências de habitações localizadas na área da Cidade Baixa e também na área da Acrópole. A maioria apresenta lareiras no interior e que podem estar relacionadas a funções sagradas ou mesmo a banquetes funerários, uma vez que a concentração de enterramentos datados desde o PG encontra-se nas proximidades (Foley 1988: 26-27). É importante lembrar que há apenas dois casos de reutilização de sepultura e ambos não apresentam oferendas, fato que, mais uma vez, singulariza o sítio no que diz respeito às práticas mortuárias. Soma-se, ainda, a independência religiosa, através da adoção do culto de

(7) Segundo a tradição literária, os driopes teriam habitado originalmente a região da Tessália, numa área denominada "Driópida, entre Mális e a Fócida, medindo trinta estádios de largura" (Heródoto VIII, 31). Segundo Heródoto e Pausânias, os driopes teriam sido expulsos dessa região por Héracles e pelos mélios e foram se instalar no Peloponeso, em Asine e Hermione (Heródoto VIII, 43; Pausânias IV, 34-9).
Apolo Pítio ainda no século VIII a.C. (Frödin; Persson 1938: 148-149, 333-334). Tais fatores indicam que a influência argiva percebida nos demais sitios da planície não é verificada em Asine e, dessa forma, a autonomia da comunidade deve ter se tornado intolerável por parte dos argivos.

Náuplia apresenta um aumento marcante do número de sepultamentos durante o GR, entretanto os vestigios habitacionais permanecem escassos. Há evidências de muros e áreas pavimentadas próximas à grande área de concentração de enterramentos. O padrão de enterramento neste sítio aproxima-se do argivo, pois a grande maioria dos enterramentos de adultos e crianças é realizada em vasos funerários, principalmente em pitos, sem a presença de oferendas. Contudo, também são vasos de grande porte e, particularmente para os enterramentos infantis em outras formas de vasos funerários, como ânforas, estas se apresentam ricamente decoradas. Apesar do aumento dos sepultamentos, a comunidade não deve ter alcançado grandes proporções. Também podemos indicar que a hegemonia argiva se faz presente no sítio, da mesma forma que em Lerna, pois as evidências habitacionais indicam que a comunidade, mesmo durante o GR, deve ter tido proporções pequenas. Devido à escassez dos contextos funerários neste último sítio, não é possivel indicar a formação de lotes. Entretanto, nota-se que a área do Monte Pontinos corresponde a uma área utilizada exclusivamente para a deposição dos mortos durante todo o Periodo Geométrico.

\section{Conclusões}

Podemos concluir, portanto, que o GR na Argólida apresenta transformações fundamentais para o processo de formação da pólis argiva. A consolidação de uma sociedade mais complexa, hierarquizada e hereditária indica que nesse subperiodo a comunidade atingiu grandes proporções, caracterizada por um processo interno de synoikismós, agrupando os pequenos núcleos de assentamentos por um lado, e expandindo as áreas comerciais e 
artesanais por outro e, ainda, fixando de forma nítida a divisão entre o espaço dos vivos e dos mortos, com a formação de necrópoles e, dentro delas, estabelecendo lotes de enterramentos especificos utilizados pelos diferentes grupos que configuram a sociedade argiva nesse momento. A ligação com um passado próximo, definido pela reutilização e pela deposição de oferendas sobre as sepulturas do GM e do GA, principalmente, denota a busca da legitimidade e da manutenção do status e do poder, fundamentados na ostentação dos enterramentos formais.

Tais mudanças fazem parte de um processo de transformações graduais iniciado já no PG, mas intensificado durante o Periodo Geométrico, no GA, e reforçado no GM. Dessa forma, o século VIII a.C. não deve ser entendido como um periodo caracterizado por elementos inovadores e nem como um renascimento (Whitley 2001: 98-101), mas sim como reafirmação, confirmação e validação. Isto não significa que não tenha sido um século revolucionário (Snodgrass 1971: 416-436), caracterizado por mudanças generalizadas no que diz respeito aos resultados sociais, culturais e politicos, apesar das nuanças e peculiaridades verificadas nas diferentes regiões da Grécia, que culmina, em última instância, na formação da pólis.

SOUZA, C.D. Mortuary practices in the Argolid between the XI and the VIII centuries BC. Revista do Museu de Arqueologia e Etnologia, São Paulo, 20: 197-217, 2010.

Abstract: This article intends to present a brief summary of the main goals and results of a PhD thesis developed at the MAE/USP about mortuary practices in the main sites of the Argolid, Greece (Map), during the Iron Age, between the XI and VIII centuries BC. This research is characterized by the process of gathering, cataloguing and analyzing the archaeological data from the funerary contexts in Argos, Tiryns, Asine, Mycenae, Nauplia and Lerna. Finally a comparison of the data collected enabled us to reach some questions and considerations about burial patterns and socio-cultural behavior in a regional perspective focused on the VIII century $\mathrm{BC}$, with the process of the rise of the Argive polis.

Key-words: Funerary contexts - Iron Age - Argolid - VIII century BC.

\section{Referências bibliográficas}

BINFORD, L.

1971 Mortuary Practices: their study and their potential In: Brown, J. (Ed.) Approaches to the social dimension of mortuary practices. American Antiquity, 36: 6-29.

\section{COURBIN, P.}

1974 Les Tombes Géométriques d'Argos, I (1952-1958). Études Péloponnésiennes VII. École Française d'Athènes. Paris: Librairie J. Vrin.
FOLEY, A.

1988 The Argolid 800-600 B.C. Studies in Mediterranean Archaeology, LXXX. Göteborg.

FRÖDIN, O.; PERSSON, A.

1938 Asine I. Results of the Swedish Excavations 1922-1930. Stockholm: Asine Committee.

HÄGG, R.

1974 Die Gräber der Argolis in sumykenischer, protogeometrischer und geometrischer 
Zeit. BOREAS, 7 (1) Lage und Form der Gräber. Uppsala.

1980 Some Aspects of the Burial Customs of the Argolid in the Dark Age. Archaiologika Analekta ex Athenon (Athens Annals of Archaeology), 13: 119-26.

1982 Zur Stadtwerdung des dorischen Argos. In: Papenfuss, F.; Strocka, V. (Eds.) Palast und Hütte. Beiträge zum Bauen und Wohnen im Altertun von Archäologen, Vor- und Frühgeschichtlern. Tagungsbeiträge eines ldt-Stiftung Bonn - Bad Godesberg veranstaltet vom 25-30 November 1979 in Berlin. Berlin: Zaberndruck, Mainz am Rhein: 297-307.

1983 Burial Customs and Social Differentiation in $8^{\text {th }}$ Century Argos. Hägg, R.; Marinatos, N. (Eds.) The Greek Renaissance of the Eight Century B. C.: Tradition and Innovation. Proceedings of the Second International Symposium at the Swedish Institute in Athens, 1-5 June, 1981. Stockholm: 27-31.

1998 Argos and Its Neighbours: Regional Variations in the Burial Practices in the Protogeometric and Geometric Periods. In: Pariente, A.; Touchais, G. (Eds.) Argos et l'Argolide. Topographie et Urbanisme. Actes de la Table Ronde Internationale 28/4 - 1/5/1990. Athènes, Argos: 131-135.

LEMOS, I.

2002 The Protogeometric Aegean: the archaeology of the late eleventh and tenth centuries BC. Oxford monographs on classical archaeology XXIV. Oxford: Oxford University Press.

MARAN, J.; PAPADIMITRIOU, A.

2006 Forschungen im Stadtgebiet von Tiryns 1999-2002. Archäologischer Anzeiger: 97-169.

MCHUGH, F.

1999 Theoretical and Quantitative Approaches to the Study of Mortuary Practice. BAR International Series, 785. Oxford: Archaeopress.

MORGAN, C.; WHITELAW, T.

1991 Pots and Politics: ceramic evidence for the rise of the Argive state. American Journal of Archaeology, 95: 79-108.
MORRIS, I.

1987 Burial and Ancient Society. The rise of the Greek city-state. Cambridge: Cambridge University Press.

PAPADIMITRIOU, A.

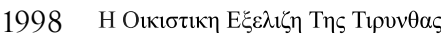

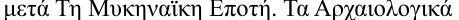

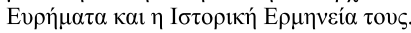
In: Pariente, A.; Touchais, G. (Eds.) Argos et l'Argolide. Topographie et Urbanisme. Actes de la Table Ronde Internationale 28/4 - 1/5/1990 - Athènes, Argos. 117-30.

2006 The Early Iron Age in the Argolid: some new aspects. In: Deger-Jalkotzy, S.; Lemos, I. (Eds.) Ancient Greece. From the Mycenaean Palaces to the Age of Homer. Edinburgh: Edinburgh University Press: 531-47.

SAXE, A.

1970 Social Dimensions of Mortuary Practices. Ph.D thesis. Michigan University: Ann Arbor. Microfilm.

SNODGRASS, A. M.

1971 The Dark Age of Greece. An Archaeological Survey of the Eleventh to the Eighth Centuries BC. New York: Routledge.

SOUZA, C. D.

2010 As práticas mortuárias na região da Argólida entre os séculos XI e VIII a.C. Tese de Doutorado. Museu de Arqueologia e Etnologia,Universidade de São Paulo. São Paulo.

UCKO, P.

1969 Ethnography and the Archaeological Interpretation of Funerary Remains. World Archaeology, 1 (2): 262-80.

WELLS, B.

1983 Asine II. Results of the Excavations East of the Acropolis 1970-1974. Fasc. 4. The Protogeometric Period. Part 2. An Analysis of the Settlement. Acta Instituti Atheniensis Regni Sueciae, Series in 4o. Stockholm: Distributor Paul Åströms Förlag.

WHITLEY, J.

2001 The Archaeology of Ancient Greece. Cambridge: Cambridge University Press. 